REVIEW

ctył@ecopetrol.com.co

\title{
MICROALGAE BASED BIOREFINERY: ISSUES TO CONSIDER
}

\author{
Ángel-Darío González-Delgado ${ }^{1}$ and Viatcheslav Kafarov ${ }^{1 *}$ \\ ${ }^{1}$ Centro de Investigación para el Desarrollo Sostenible en Industria y Energía, Industrial Universidad Industrial de Santander, \\ Bucaramanga, Colombia \\ e-mail: cisyc@uis.edu.co kafarov@uis.edu.co
}

(Received Jul. 01, 2011 ; Accepted Nov. 09, 2017)

\begin{abstract}
$\mathrm{B}$ iorefining is sustainable biomass processing to obtain energy, biofuels and high value products through processes and equipment for biomass transformation. The biorefinery concept has been identified as the most promising way to create a biomass-based industry. Microalgae are classified as promising candidates in biorefinery processes because they are particularly important for obtaining multiple products. This review article describes the biorefinery concept taking into account its different interpretations and comparing it with the traditional biomass transformation processes. It describes the general characteristics of microalgae, and their potential to be used as a raw material in the biorefinery process. The review focuses on the state of the art of products obtained from microalgae for the biofuel industry, mainly for biodiesel production, and the different methods to extract oil for biodiesel production as well as other products. Based on this information, several aspects are suggested to be taken into account for the development of a topology for a microalgae-based biorefinery.
\end{abstract}

Keywords: Biofuels, Biomass processing, Bioindustries, Biomass, Microalgae, Biorefinery.

Citation: González-Delgado, A. D. \& Kafarov, V. (2011). Microalgae based biorefinery: Issues to consider. A review. CT\&F - Ciencia, Tecnología y Futuro, 4 (4), 5 - 22.

*To whom correspondence should be addressed 


\section{RESUMEN}

iorefinar es procesar biomasa de forma sostenible para obtener biocombustibles, productos comercializables y energía mediante procesos y equipos para la transformación de biomasa. El concepto de biorefinería ha sido identificado como el camino más prometedor para la creación de una industria basada en la biomasa. Las microalgas se catalogan como candidatas promisorias en procesos de biorefinería, siendo particularmente importantes por la obtención de múltiples productos. Este artículo de revisión, describe el concepto de biorefinería teniendo en cuenta sus diferentes interpretaciones y se compara con los procesos tradicionales de transformación de biomasa, se describen las características generales de las microalgas, y su potencial para ser utilizadas como materia prima en procesos de biorefinería, la revisión se enfoca en el estado del arte de los productos obtenidos de microalgas de interés para la industria de los biocombustibles y los diferentes métodos de extracción tanto de aceite para la producción de biodiesel como de otros productos y con base en esta información, se sugieren algunos aspectos a tener en cuenta para el desarrollo de una topología de biorefinería basada en microalgas.

Palabras claves: Biocombustibles, Procesamiento de biomasa, Bioindustrias, Biomasa, Microalga, Biorrefineria.

\section{RESUMO}

$\mathrm{B}$ iorefinar é processar biomassa de forma sustentável para obter biocombustíveis, produtos comercializáveis e energia mediante processos e equipamentos para a transformação de biomassa. $\bigcirc$ conceito de biorefinaria tem sido identificado como o caminho mais prometedor para a criação de uma indústria baseada na biomassa. As microalgas são catalogadas como candidatas promissoras em processos de biorefinaria, sendo particularmente importantes pela obtenção de múltiplos produtos. Este artigo de revisão descreve o conceito de biorefinaria considerando suas diferentes interpretações e faz comparação com os processos tradicionais de transformação de biomassa, são descritas as características gerais das microalgas e seu potencial para serem utilizadas como matéria-prima em processos de biorefinaria, a revisão é enfocada no estado da arte dos produtos obtidos de microalgas de interesse para a indústria dos biocombustíveis e nos diferentes métodos de extração tanto de óleo para a produção de biodiesel como de outros produtos e, com base nesta informação, são sugeridos alguns aspectos a serem considerados para o desenvolvimento de uma topologia de biorefinaria baseada em microalgas.

Palavras-chaves: Biocombustíveis, Processamento de biomassa, Bioindústrias, Biomassa, Microalgas, Biorefinaria. 


\section{INTRODUCTION}

At present, the continued use of petroleum-based fuels is recognized as unsustainable due to the exhaustion of supplies and their contribution to environmental pollution. In order to decrease the $\mathrm{CO}_{2}$ emissions causing global warming, fossil fuels have to be replaced with clean, renewable energy (Amin, 2009). In response to this issue, environmental policies have favored the increase in research, development and the use of biofuels around the world, mainly those that can replace the fossil fuels used in transportation (Demirbas, 2008). Biofuels offer many benefits associated with energy security, economic stability and reducing the environmental impact of greenhouse gases (Hoekman, 2009).

First-generation biofuels are derived from crops such as sugar cane (Goldemberg, Coelho \& Guardabassi, 2008), beet (Mortimer, Elsayed \& Horne, 2004), corn (Franceschin, Zamboni, Bezzo \& Bertucco, 2008), and soy (Olivares-Carrillo \& Quesada-Medina, 2011). They are produced from sugars, vegetable oils or animal fats using conventional technologies such as fermentation and transesterification, the most common being biodiesel, bioethanol and biogas. Currently, the biofuels in which the most effort has been invested are ethanol from sugar cane (Dias et al., 2010) and corn, and biodiesel from oilseed sources (Singh \& Singh, 2010). The advantages of first-generation biofuels lie in the high productivity of the crops used to obtain the raw materials (oil and sugar), a fully established cropping pattern, ease to extract the raw material and a mature technology for transforming them into biofuels (ethanol or biodiesel). However, the sustainability of the production of these biofuels has been strongly challenged by the great demand of surface for crops required for their production (Mueller, Anderson \& Wallington, 2011). In addition, they compete with the food industry over the use of the same raw material and the need for arable land for crop development (Naik, Goud, Rout \& Dalai, 2010). Their production gives rise to enormous tension on global food markets. It has even been said that the balance of carbon from bioethanol made from corn can be less favorable than that generated by using fossil fuels (Searchinger et al., 2008).

Second-generation biofuels are produced from a variety of raw materials that do not compete with food sources. These include lignocellulosic material resulting from agro-industrial activities such as the extraction of sugar (Ojeda, Ávila, Suárez \& Kafarov, 2010), or oil (cane bagasse, palm heart), rice husks and waste from the production of corn, among others (Carriquiry, Xiaodong \& Govinda, 2011). Secondgeneration biofuels promise to be more beneficial than first-generation biofuels in terms of efficient use of land and proper environmental management. Most processes and technologies for the production of third-generation biofuels are still in the pre-commercial stage (pilot plants, demonstration plants) (Goh \& Lee, 2011). These biofuels have not faced the problems mentioned above for first-generation biofuels. However, there is major concern about competition in the use of the soil and the changes caused thereto (Nigam \& Singh, 2011).

Third-generation biofuels are also called advanced biofuels, due to the raw materials and technological processes used to produce them. These biofuels are derived specifically from micro-organisms as microbe and microalgae. Based on current scientific knowledge and the projections of technology, they are considered a viable energy resource without the disadvantages associated with those of the first and second-generation biofuels (Singh \& Singh 2010). Microalgae are a promising feedstock for the production of third-generation biofuels (Mata, Martins \& Caetano, 2010). Microalgae are single-celled photosynthetic organisms that are located in different environments, under a wide range of temperatures, $\mathrm{pH}$ and nutrient availability. They have a growth rate between 20 and 30 times greater than other sources of biofuels, growing throughout the year in warm, tropical, and subtropical climates. Their productivity rate is greater than land crops and can be harvested 365 days a year (Chisti, 2007), reason for which they have the potential to form a continuous biofuel production chain like traditional oil refineries. In addition, microalgae have a very high photosynthetic efficiency. Therefore, microalgae cultures contribute in a great way to the sequestration of atmospheric $\mathrm{CO}_{2}$. They satisfy the criteria proposed by Schenk et al, (2008) to achieve economic and environmental sustainability of biofuel production.

However, the progressive replacement of oil with biofuels will require certain changes in the current production of goods and services. In this transformation, biology, chemical engineering and petroleum enginee- 
ring will play an important role, along with the synergies that can develop among these disciplines (Kamm, Kamm, Gruber \& Kromus, 2006). The production of biofuels for transportation is one of the most important factors to promote the future development of biorefineries (Biofuels Research Advisory Council, 2006).

\section{THE BIOREFINERY CONCEPT}

The term biorefinery has been a part of scientific literature since 2001 (Wyman, 2001). However, in the year 2007, it began to take on an increased significance in publications and reports of scientific events. The term biorefinery has been defined in several ways. The International Energy Agency says that biorefining is processing biomass in a sustainable manner within a spectrum of marketable products and energy (IEA Bioenergy, 2007). This concept can be extended, according to Cherubini (2010), to a laboratory or a set of laboratories that integrates biomass transformation processes and equipment for the production of fuels for transportation, energy and chemicals.

This concept can be compared to the current concept of oil refineries as regards the fractioning of a complex mixture. However, there are two major elements that make them different: the first is the raw material, because those used in biorefinery have not undergone the biodegradation of crude oil over time; so the possibilities of obtaining more products using biomass as a feedstock are greater; and the second is the application of different existing and emerging technologies in order to obtain bioproducts.
Biorefining involves assessing and using a wide range of technologies to separate biomass into its principal constituents (carbohydrates, protein, triglycerides, etc.), which can subsequently be transformed into value-added products and biofuels through the application of other processes.

The country that has focused its research on this topic the most is the United States, although Canada, England, Germany, China, Japan and Spain are also doing so to a lesser extent. Table 1 shows some elements that differentiate the industrial processes that are currently used without applying this concept and the impacts of including biorefining complexes to said processes.

The palette of products from a biorefinery not only includes the products obtained in an oil refinery, but also products that cannot be obtained from crude. Biorefineries can produce energy in the form of heat or by producing biofuels, molecules for fine chemistry, cosmetics or medicinal applications, materials such as plastics and sources of human food and animal feed. Figure 1 illustrates the generalized outline of a biorefinery.

A major impact generated by implementing this concept is related to the sustainable use of local biodiversity, because in the case of the combined production of biofuels and co-products, the sustainable production of biofuels can be achieved by using waste, which reduces fuel imports, leading to self-sufficiency based on raw materials available at the local level. This directly involves research based on the availability and characteristics of biomass sources specific to each region and the assessment of technologies for the sustainable separation and transformation of biomass components.

Table 1. Differentiation between biomass transformation processes and biorefining.

\begin{tabular}{|c|c|}
\hline Biomass transformation processes & Biorefining \\
\hline - Linear production chains & - Combination of flows of matter from several bioindustries \\
\hline - Materials in competition with food & - Reduction in the competition with fertile land by making use of waste \\
\hline - Limited exploitation & - High productivity of bioproducts per unit area \\
\hline - Consumption of non-renewable energy & - Consumption of a high percentage of energy from biomass \\
\hline - Urban industrial zones & - Positive environmental impact \\
\hline - Major industrial complexes (oil refinery) & - Expectation of revitalizing rural areas \\
\hline
\end{tabular}




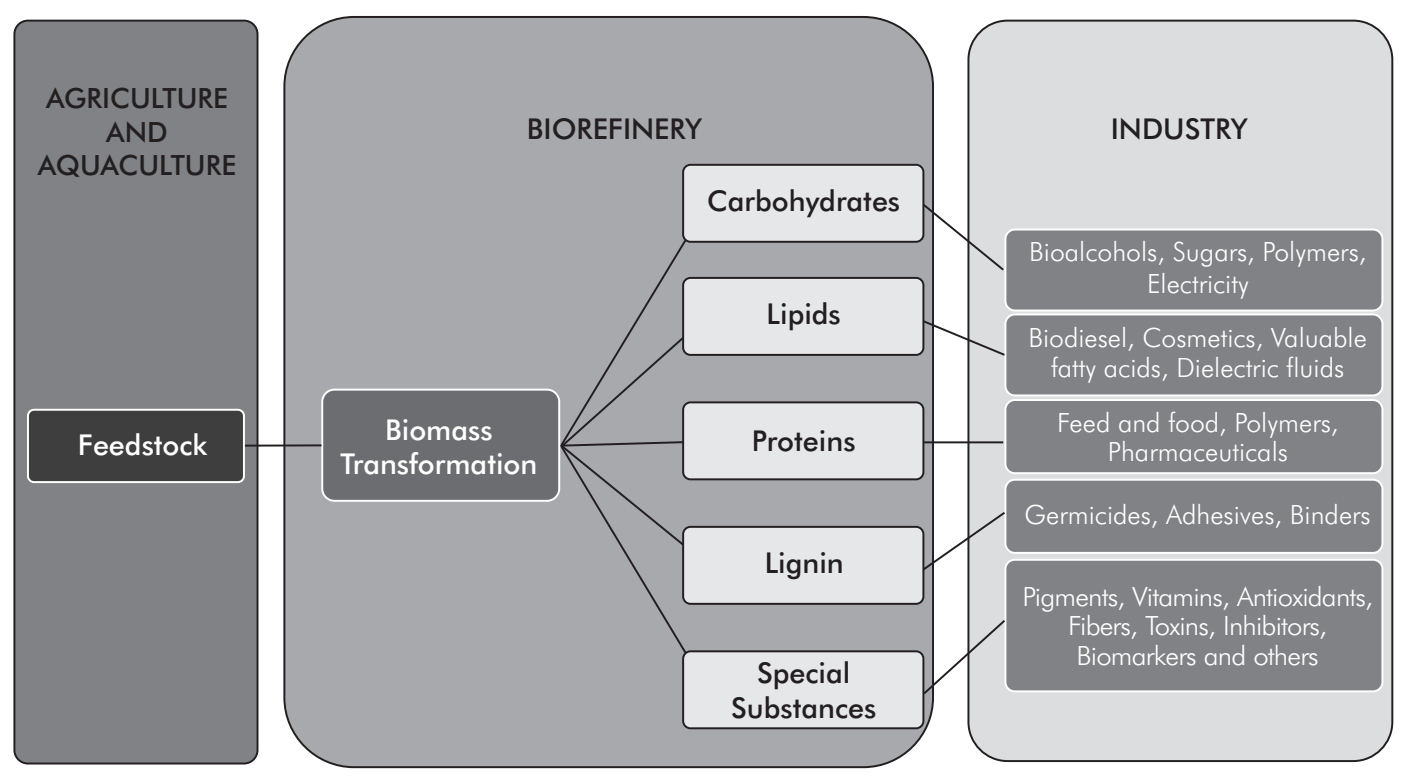

Figure 1. General outline of the biorefinery concept.

\section{BIOMASS PROCESSING IN BIOREFINERY}

If the goal of biorefineries is to transform biomass into biofuels and high value-added products, the existing and emerging technologies for these transformations have to be reviewed, because in biorefining, these technologies must be applied together. Among the advances necessary for the operation of a biorefinery, Taylor (2008) suggests understanding the mechanisms of construction and destruction of the cell walls of the raw materials, the development of new plants with different characteristics, the implementation of biomass transformation processes as a function of the composition there of, interdisciplinary tasks and the development of new technologies focused on the raw materials.

These processes can be divided into physical processes, which involve mechanical action for the homogenization, destruction, separation or decrease in biomass particle size, for instance, for the transformation of waste from growing corn (Li et al., 2004), or the hydrogenation of bio-oil by agitation (Xiong, Fu, Zeng $\&$ Guo, 2011). Thermal processes, such as gasification to produce synthesis gas (Spath \& Dayton, 2003), or pyrolysis to produce bio-oil, biogas and biocoal (Grierson,
Strezov, Ellem, McGregor \& Herbertson, 2009); chemical processes such as hydrolysis, which can be acidic, basic or enzymatic processes used in first and second generation bioethanol production processes (Kumar, Barrett, Delwiche \& Stroeve, 2009); esterification and transesterification (Berrios, Martín, Chica, \& Martín, 2010) and biochemical processes, such as anaerobic digestion, in which biogas is produced by degrading biomass through bacteria (Holm-Nielsen, Al-Seadi \& Oleskowicz-Popiel, 2009), or fermentation, which uses enzymes and/or microorganisms to transform fermen-table substrates such as pentose and hexoses in organic acids or alcohols.

\section{MICROALGAE AS A RAW MATERIAL IN BIOREFINERIES}

Microalgae are a heterogeneous group of photosynthetic single-cell prokaryote (cyanobacteria) and eukaryote microorganisms, which are located in various environments, under a wide range of temperatures, $\mathrm{pH}$ and nutrient availability conditions (Meng et al., 2009). Their biodiversity is enormous, estimated at more than 50000 species of which only around 30000 have been 
analyzed and studied (Richmond, 2004). They are classified according to several parameters such as pigmentation, life cycle, morphology and cell structure.

In principle, microalgae require a smaller area to grow than soybean or other crops to produce the same volume of biofuel. They can be grown in tanks built on marginal land anywhere (Molina-Grima, Acién-Fernández, García-Camacho \& Chisti, 1999.), so they do not compete with food production and do not cause negative environmental and social impacts. It is an energy source that is continuous, inexhaustible and non-polluting that can play a role in mitigating the greenhouse gas effect and restoring the thermal balance of the planet because it does not mobilize fossil carbon, but rather uses the excess atmospheric carbon $\left(\mathrm{CO}_{2}\right)$ generated by burning fossil fuels over decades.

\section{PRODUCTS OBTAINED FROM MICROAL- GAE RELATED TO BIOFUEL INDUSTRY}

In the field of biofuels, microalgae can provide raw material for different types of renewable fuels such as biodiesel, methane, hydrogen and ethanol, among others (Harun, Singh, Forde \& Danquah, 2010). In recent years, they have attracted the attention of research due to their biotechnological potential, and they are presented as an alternative that promises to satisfy or replace the global demand for petrodiesel (Garibay-Hernández, Vázquez-Duhalt, Sánchez-Saavedra, Serrano-Carreón, \& Martínez-Jiménez, 2009). The species that have been studied most for biotechnological applications are green microalgae and diatoms (Vázquez-Duhalt \& ArredondoVega, 1991).

\section{Biodiesel}

As regards products related to the fuel industry, some genera of microalgae contain high percentages of triglycerides (three chains of fatty acids joined by a glycerin molecule), di-glycerides and monoglycerides in their lipid profile, so biodiesel and glycerin can be obtained from their oil through a transesterification reaction that replaces the glycerin with methanol or ethanol using an alkali/acid as catalyst, forming Fatty Acid Methyl Esters (FAME) or Ethyl Esters (FAEE).
Glycerol is obtained as by-product, and is separated from biodiesel by phase separation.

As alternative, vegetable oils produced by the microalgae can be subjected to hydrotreatment for the production of Green diesel. This procedure presents an additional advantage, which consists of the possibility of using the structure existing in traditional oil refineries in order to carry out the oil transformation process. Biodiesel is currently produced in commercial scale by companies such as Solazyme Inc. (www.solazyme. com) who separates their biofuels in SoladieselBD ${ }^{\circledR}$, SoladieselRD ${ }^{\circledR}$ and SoladieselHRF-76 ${ }^{\circledR}$ depending on its properties and applications.

\section{Lipid concentration of microalgae strains}

According to information from the US Department of Energy (www.doe.gov), some microalgae species have the ability to produce up to 100 times more oil per hectare than palm oil, and they are now profiled as the only viable alternative to raw material viable to replace petroleum-based liquid fuels in the future, because there is no other absorber of solar radiation more effective than these photosynthetic organisms (Molina, Fernández, Acien \& Chisti, 2001). The oil content of certain strains in some cases exceeds $80 \%$ in dry weight biomass under appropriate conditions (Table 2). In fact, they have the highest oil output compared to several alternative plantbased energy sources

Depending on the species, microalgae produce different types of lipids, hydrocarbons and other compounds (Amaro, Guedes \& Malcata, 2011). The main components of the lipid fraction are triacylglycerols, free fatty acids, waxes, sterols, hydrocarbons, glycolipids and phospholipids (Li, Horsman, Wang, Wu \& Lan, 2008). Not all algae oils are suitable for manufacturing biodiesel, but the presence of adequate oils is very common and often constitutes $20 \%$ to $40 \%$ of the total lipids (Chisti, 2008). However, their importance is related to the quality of the fatty acids produced, where the majority is composed of unsaturated fatty acids. Triglycerides are the most useful for manufacturing biodiesel (Amaro et al., 2011).

The variation in the fatty acid profile among the different groups of microalgae is considerable. This is mainly 
due to nutritional and environmental factors, growing conditions and growth stages. In addition, the method used for both cell disruption and for the extraction of oil from microalgae can affect the final profile of the fatty acids obtained, since extreme operating conditions can break bonds and modify the chains of said acids.

Table 2. Lipid content of several species of marine afreshwater microalgae (modified from Mata et al., 2010).

\begin{tabular}{|c|c|}
\hline $\begin{array}{l}\text { Strains of marine and } \\
\text { freshwater microalgae }\end{array}$ & $\begin{array}{c}\text { Total lipid content } \\
\text { (\% in dry weight biomass) }\end{array}$ \\
\hline Ankistrodesmus sp. & $24-31$ \\
\hline Botriococcus braunii & $25-75$ \\
\hline Chaetoceros calcitrans & $14,6-39,8$ \\
\hline Chlorella emersonii & $25-63$ \\
\hline Chlorella protothecoides & $14,6-57,8$ \\
\hline Chlorella vulgaris & $5-58$ \\
\hline Chlorella sp. & $10-48$ \\
\hline Chlorococcum sp. & 19,3 \\
\hline Dunaliella sp. & $17,5-67$ \\
\hline Dunaliella tertiolecta & $16,7-71,0$ \\
\hline Hemmatococcus pluvialis & 25 \\
\hline Isochrysis galbana & $7-40$ \\
\hline Nannochloris sp. & $20-56$ \\
\hline Nannochloropsis oculata & $22,7-29,7$ \\
\hline Nannochloropsis sp. & $12-53$ \\
\hline Neochloris oleabundans & $29-65$ \\
\hline Pavlovalutheri & 35,5 \\
\hline Phaeodactylum tricornutum & $18-57$ \\
\hline Porphyridium cruentum & $9-60,7$ \\
\hline Scenedesmus obliquus & $11-55$ \\
\hline Spirulina maxima & $4-9$ \\
\hline
\end{tabular}

\section{Biogas}

Anaerobic digestion can be applied on microalgae biomass to produce biogas, which is composed mainly by methane and carbon dioxide. This methane is used as fuel itself or can be used to produce other kinds of energy through combustion. This process shows different yields depending on microalgae strain used, reaching values from $0,2 \mathrm{~m}^{3} / \mathrm{kg}$ to $0,5 \mathrm{~m}^{3} / \mathrm{kg}$ (Harun et al., 2010). Operating conditions for microalgae biogas production using anaerobic digestion must be optimized, taking into account reaction conditions (mesophilic or thermophilic), temperature, time, organic loading, solid retention time and $\mathrm{pH}$. Main challenge of this technology is related with the reduction of production costs in comparison with other feedstocks, for this reason, among others, commercial production of biogas form microalgae is not implemented yet.

\section{Bioethanol}

In addition to lipids, microalgae biomass contains cellulose and hemicellulose, which can be used as a source of carbon in fermentation processes to produce ethanol (Harun \& Danquah, 2011). An advantage of microalgae, in comparison with other crops used for bioethanol production, is their low lignin content, which is almost null in some strains. This allows skipping the biomass pre-treatment stage to perform the hydrolysis of cellulosic material directly. According to Moen (2008), brown microalgae gives higher bioethanol yields in comparison with other algae species. These natural polymers have been used to obtain the reducing sugar from microalgae in multifunctional processes with a view to the joint production of biodiesel and bioethanol (González \& Kafarov, 2010). Ueda, Hirayama, Sugata and Nakayama (1996) and Bush and Hall (2006), patented processes for the production of ethanol from microalgae.

A type of bluish green microalgae called cyanobacteria produce bioethanol naturally without the need to implement methods to process biomass components (Amin \& Wijffels, 2004). Since this bioethanol is the product of the metabolic activities of the strains, it can be extracted in vivo by milking, i.e. the addition of substances to the culture medium to stimulate the excretion of the desired product without the need for genetic manipulation.

Bioethanol production from microalgae shows a couple of advantages in comparison to biodiesel production from the same feedstock. Related with the simplicity and energy requirements of the process, it must also be taken into account that carbon dioxide is a co-product of 
the fermentation reaction of sugars for bioethanol production. This co-product can again be fed at the cultivation stage as food for the microalgae, however, microalgae bioethanol production is still under study and there is no commercial production of this third generation biofuel.

\section{Biobuthanol}

This biofuel has the advantage of its use directly in vehicles without modifications in the device owing to its low vapor pressure that allows the easy mixing with fossil gasoline, these products correspond to a potential application of microalgae biomass for biofuels industry and must be researched deeply.

\section{Reported methods to obtain products from microalgae}

There are several methods used to extract specific components from microalgae biomass, which can be broken down into chemical methods, mechanical methods, and enzymatic methods. The extraction of lipids with solvents has been used traditionally to obtain lipids from animal and plant sources. In the case of microalgae, the solvent selective toward the metabolite of interest is usually added to the dry biomass, although in some cases a certain amount of water is allowed in order to reduce the overall costs of the process, and also diminishing extraction efficiency, extraction combined with in-situ transesterification can also be performed (Ehimen, Sun \& Carrington 2010).

\section{Solvent based methods}

A wide variety of organic solvents are often used to extract oil from microalgae, where hexane and ethanol are the most popular. A hexane-ethanol mix can be used to extract more than $98 \%$ of the fatty acids present in the biomass (Richmond, 2004). However, since ethanol is relatively polar, its selectivity to lipids is relatively low compared to other solvents, so in extractions with ethanol, other microalgae components may also appear, such as sugars, pigments or amino acids. A solvent-based methodology was proposed by Folch, Lees and Stanley (1957) to extract both polar and non-polar lipids, due to the use of an apolar solvent that dissolves neutral lipids, in combination with a relatively polar solvent, which dissolves the polar lipids present in the sample undergoing extraction. The original method was based on the methanol/chloroform mix, followed by a purification of the extracts with a $\mathrm{KCl}$ solution. After that, Bligh and Dyer (1959), modified Folch's method, and obtained a quick lipid extraction method, which is currently being used and has been tested successfully in extracting oil from algae (Molina-Grima et al., 1994). This method has obtained good results in extracting oil from microalgae and is often used as a complement to mechanical destruction methods or biomass treatment with autoclave, although it poses the disadvantage of not being very environmentally friendly due to the toxicity of the solvents used, therefore preventing its utilization at an industrial scale.

The soxhlet extraction system has been widely used to extract oil from algae (Manirakiza, Covaci, \& Schepens, 2001; Córdoba, López, González \& Kafarov, 2010). Petroleum ether and ethyl ether have been used with this system to extract non-polar lipids from microalga Neochloris oleobundans (Li et al., 2008). The inconvenience with ethers, is their volatility, which leads to a significant loss of solvent during the extraction process. Hexane has also been evaluated as an extraction solvent for microalgae in the soxhlet system with interesting results (Anderson \& Sorek, 2008). The advantage of hexane is that it is three times cheaper under local market conditions than other non-polar solvents as cyclohexane, easy-to-recover after extraction and it is selective to neutral lipids. In addition, it can be used in mixture with isopropanol (Li et al., 2008), which is considered safe in an industrial scale and is used for lipid extraction from soybean, efficient in the extraction of fatty acids and has a low level of toxicity. The dichloromethane/hexane mixture allows the increase in the amount of total lipids extracted, if the objective is high efficiency and selectivity is not a priority. Another mixture that has been used successfully in soxhlet extraction for microalgae, is the combination of dichloromethane/methanol (Anderson \& Sorek 2008), which recovers a large amount of neutral lipids. Soxhlet extraction is a typical lab-scale extraction method and is not applied in big scale itself. However, it is considered a method for the simulation of a multi-step solvent extraction with continuous reflux.

\section{Microwave-assisted Extraction}

Microwave-assisted extraction is characterized for being a technique that reduces process time and increases process efficiency (up to twice that of the other techniques). This method was compared with other methods that included a pre-treatment or biomass conditioning stage by cell destruction procedures such as autoclave, ball mill, induced resonance and osmotic shock, all followed by extraction using the methanol-chloroform mixture 
for the species Chlorella vulgaris, Scenedesmus sp. and Botryococcus sp. (Lee, Yoo, Jun, Ahn \& Oh, 2010), the results shown that the highest oil yield increase for all microalgae strains evaluated was reached when the cells were disrupted using the microwave oven method. Origin Oil company exhibits a harvesting/oil extraction technology based on applying the electromagnetic fields that currently is scaling up in Australia.

\section{Ultrasound-assisted Extraction}

The ultrasound technique consists of exposing the microalgae to sound waves of a specific frequency (low), to destroy the cell wall (Pernet \& Tremblay, 2003). Cravotto et al. (2008) developed an extraction technique with ultrasound and assisted by microwaves simultaneously, working at frequencies between 19 and $300 \mathrm{kHz}$, with which they obtained a significant decrease in extraction time, reducing it up to 10 -fold and increasing oil extraction yield by $50-500 \%$ for seaweed oil extraction in comparison with conventional methods as soxhlet. A technology based in this extraction method is used at big scale for microalgal lipid extraction by the Fox Oil Company in Argentina.

\section{Supercritical Extraction Methods}

There are also methods to extract components from microalgae called supercritical, as an alternative to the traditional use of large quantities of toxic solvents to perform extractions. Among this kind of processes, the most promising ones are supercritical fluid extraction (SFE), and subcritical water extraction (SWE), which are characterized by short extraction times and high selectivities (King, 2000). In addition, they are eco-friendly and present high efficiencies in the extraction of solid samples. One characteristic that makes the use of SFE interesting is the possibility of combining the extraction system with in line characterization systems such as gas chromatography, or supercritical fluid chromatography (Chester \& Pinkston, 2004). This method has been tested in lab-scale with good results; however, the high costs associated with operation conditions for the extraction makes difficult the scaling-up of this technology.

SFE has been used with several species of microalgae to obtain different substances: Cheung (1999) used supercritical $\mathrm{CO}_{2}$ to obtain Omega-3 fatty acids from Hypneacharoides; Mendes et al. (1995) and Mendes, Nobre, Cardoso, Pereira and Palavra (2003) applied the technique to extract carotenoids from Chlorella vulgaris, b-carotene from Dunaliella salina and diolefinas from Botryococcus braunii.

In extraction using subcritical water (SWE), water is used at temperatures between 100 and $374^{\circ} \mathrm{C}$, and pressures between 10 and 60 bar (Herrero, Cifuentes \& Ibáñez, 2006), to keep it in a liquid state. Under these conditions, the dielectric constant of the water decreases considerably, approaching the dielectric constant of ethanol at room temperature. This method of extraction has been used in microalgae by Herrero, Ibáñez, Señoráns and Cifuentes (2003), who obtained antioxidative components from the microalga Spirulinaplatenses.

\section{Autoclave}

Use of an autoclave to extract metabolites from microalgae is a variable methodology and used in lab-scale: Minowa, Yokoyama, Kishimoto and Okakurat (1995), used an aqueous saline solution as a working fluid in an autoclave at $300^{\circ} \mathrm{C}$, and a pressure of $100000 \mathrm{kPa}$, residence times between 5 and 60 minutes, and they used nitrogen to purge residual air. Álvarez, González and Kafarov (2011), used different autoclave times at $121^{\circ} \mathrm{C}$ and $0,72 \mathrm{kPa}$ to increase efficiency in the extraction of lipids for Nannochloropsis sp.

\section{Enzyme-assisted Extraction}

In enzyme-assisted extraction, the cell wall of the microalgae is degraded with enzymes, which facilitates the withdrawal of the oils in the cell. Enzymes can also be used to transform the fatty acids present in the microalgae in lipids suitable for subsequent transesterification (Ward $\&$ Singh, 2005). However, enzymatic activity is affected by many variables, such as the nature and concentration of the enzyme, the concentrations and ratios of the reactants, the composition of the oils or fatty acid mixtures, the composition of the cell wall, the initial water content and temperature, among others (Robles-Medina, MolinaGrima, Giménez-Giménez \& Ibáñez-González, 1998).

\section{Extraction Assisted by Mechanical Destruction}

Mechanical destruction as a tool to extract components from microalgae, covers several classes of mechanical devices such as cell homogenizers, ball mills and prewssing systems, among others. Lee, Yoon and Oh (1998) evaluated several mechanical destruction systems to extract lipids from the microalga Botryococcus braunii 
concluding that a higher oil extraction percentage is obtained by using a mill with glass balls $1 \mathrm{~mm}$ in diameter, for one minute. This method is not suitable for using at lab-scale because of the high biomass losses during its utilization and low selectivity to lipids, however, the use of mechanical destruction becomes convenient in bigger scale, the disadvantage of mechanical destruction methods is the difficulty to recover the extracted oil, and the release of other substances present within the cell. These methods should be used in combination with extraction methods using solvents.

\section{Obtaining Other Products}

The extraction of pigments from microalgae is achieved by breaking the cells, extraction using solvent or buffer solution, followed by centrifugation to separate the extract from the residual biomass. This filtering can be purified and sterilized partially by microfiltration and spray-dried or freeze-dried (Henriques, Silva \& Rocha, 2007).

The carotenoid pigments from the biomass of Dunaliella salina have been obtained through saponification of the alcoholic extract (to separate them from the chlorophyll), followed by extraction with an apolar solvent. The biomass of Chlorella vulgaris has been extracted with $95 \%$ alcohol and acetone, and separation of the components of these extracts has been carried out by thin plate column chromatography, using different adsorbents: dextran T40, hydrolyzed starch, sucrose and cellulose (Gong Bih Enterprise Limited Company, 2002).

As regards enzyme-assisted extractions, the two-phase biocatalysis of whole cells is a very interesting method to extract bioactive metabolites of high-values present in the microalgae cells. In this procedure, the cells take the dodecane (up to $13 \mathrm{pg} / \mathrm{cell}$ ), an organic solvent added to stimulate the continued release in vitro and in vivo of $\beta$-carotene and its biosynthesis. Due to this "milking" process, larger quantities of $\beta$-carotene can be produced than in the traditional process of commercial production. This method was applied on Dunaliellasalina, a singlecell microalgae known as one of the richest sources of $\beta$-carotene.

Mendes-Pinto, Raposo, Bowen, Young and Morais (2001) extracted the carotenoids from the microalgae Haematococcus pluvialis in autoclave at $121^{\circ} \mathrm{C}$ and 1 atm (1 bar), for 30 minutes, obtaining a higher extraction percentage than the other techniques evaluated, such as Spray Drying or enzymatic treatments.

The implementation of the technology to obtain biomethane in microalgae raises interest because microalgae biomass has very little lignin, which favors the conversion efficiency and stability of the anaerobic digestion process. Biogas production by anaerobic digestion is greatly affected by temperature, organic load, $\mathrm{pH}$ and residence time. Anaerobic digestion can be carried out both in mesophilic and thermophilic conditions (Otsuka \& Yoshino, 2004).

\section{WATER REQUIREMENTS FOR MICROAL- GAE CULTURE}

There is an interesting discussion related with impacts of large-scale microalgae-based bioproducts related with water usage. For example, the national algal biofuels technology roawdmap presented by the US Department of Energy (www.doe.gov) critiques large-scale microalgae biodiesel production for the great amount of freshwater usage. These high freshwater requirements can be lower than conventional feedstock-based biodiesel production if microalgae are grown in other water sources as seawater or wastewater.

Water footprint of microalgae does not depend on oil content, but depends in a great way of biomass concentration in culture medium, depending of culture conditions (substrates, $\mathrm{pH}$, nutrient limitation, culture technology, etc.) this concentration may vary beetwen 0,5 and 200 $\mathrm{g} / \mathrm{L}$, microalgae cultivation in photobioreactors shows higher cell concentrations in comparison with cultivation in open ponds, because of the control of environmental variables, heterotrophic culture of genetically modified microalgae patented by Solazyme, an American renewable oil and bioproducts company increase in a great way biomass concentration decreasing water requirements, for autotrophic cultures, microalgae water footprint can be decreased significantly if the culture medium after harvesting process is recycled (Yang et al., 2011), for this reason, an important issue to consider is the management of culture conditions in order to obtain a high cell density and easiness of re-use the culture medium. 


\section{PRODUCTION COSTS}

Production costs of microalgae culture must be taken into account for the development of microalgae based biorefineries. Heterotrophic culture gives higher oil productivites than other cultivation conditions, however, this culture can get contaminated easily, especially in open ponds, causing problems in large-scale production. Organic carbon source costs must be taken into account; in this aspect, the biorefinery concept can also be applied because organic residues from other bioindustries (Switchgrass, forest residues, glycerol, corn stovers and other waste streams) can be used as carbon source. Phototrophic cultivation has a lower cost for scaling-up and becoming attractive for a large scale investment; operation costs for mixotrophic and photoheterotrophic are high because of the need to use a special photobioreactor for scaling-up in order to avoid contamination risk and satisfy light requirements (Chen, Yeh, Aisyah, Lee \& Chang, 2011).

Production costs of biodiesel from microalgae are until now higher when comparing with conventional fuels. There are few studies about it, and this is because of the novelty of the process; however, biodiesel production costs exhibit economies of scale. All stages involved in microalgal biodiesel production chain require high energy, thus contributing in high production costs. $\mathrm{Cu}-$ rrent studies show that production of microalgae is too expensive for biodiesel use alone, this is another reason to conduct microalgal research in the biorefineries field. Table 3 shows a comparison of microalgae with other raw materials to be used as biodiesel source, information was collected by previous studies developed by several authors (Mata, Martins \& Caetano, 2010; $\mathrm{Xu}$, Miao \& Wu, 2006; Santana et al., 2010; Clarens, Resurreccion, White \& Colosi, 2010; Gerbens-Leenes, Hoekstra \& Meer, 2009; Hincapié, Mondragón \& López, 2011, Mekonnen \& Hoekstra, 2011, Yang et al., 2011; Demirbas, 2007; Yusuf, Kamarudin \& Yaakub, 2011; Amaro et al., 2011; Fore, Lazarus, Porter \& Jordan, 2011).

\section{ENVIRONMENTAL IMPACTS}

As photosynthetic organism, microalgae require sunlight, carbon dioxide and water. $\mathrm{CO}_{2}$ sequestration by microalgae mass cultures represent a significantly positive environmental impact, $1,8 \mathrm{~kg}$ of $\mathrm{CO}_{2}$ are required to produce $1 \mathrm{~kg}$. of microalgae biomass, this stage can enable the utilization of fossil $\mathrm{CO}_{2}$ streams from concentrated sources. Modification of Greenhouse gases (GHG) emissions would result from the utilization of microalgae biomass for renewable biofuels production (Demirbas, 2008). In addition, microalgae do not have a significant environmental impact to humans and do not have much of an eco-toxic effect, such as acidification or eutrophication.

Table 3. Comparison of microalgae with other raw materials for biodiesel production.

\begin{tabular}{|c|c|c|c|c|c|c|c|}
\hline $\begin{array}{c}\text { Raw } \\
\text { Material }\end{array}$ & $\begin{array}{c}\text { Oil } \\
\text { Content } \\
\text { (\% in dry } \\
\text { weight } \\
\text { biomass) }\end{array}$ & $\begin{array}{c}\text { Output } \\
\text { (L oil/ha year) }\end{array}$ & $\begin{array}{l}\text { Land used } \\
\text { (m² year/Kg } \\
\text { biodiesel) }\end{array}$ & $\begin{array}{l}\text { Water } \\
\text { Footprint } \\
\text { (m³/ton) }\end{array}$ & $\begin{array}{c}\text { Production } \\
\text { Cost } \\
\text { (US\$/L) }\end{array}$ & $\begin{array}{c}\text { Acid } \\
\text { value of } \\
\text { oil }\end{array}$ & $\begin{array}{c}\text { Biodiesel } \\
\text { yield }\end{array}$ \\
\hline Soybean & 18 & 636 & 18 & 4200 & $0,40-0,60$ & 0,2 & $90 \%$ \\
\hline Rapeseed & 41 & 974 & 12 & 4300 & 0,99 & 2,0 & $87 \%$ \\
\hline Sunflower & 40 & 1070 & 11 & 6800 & 0,62 & 0,1 & $90 \%$ \\
\hline Palm & 36 & 5366 & 2 & 5000 & 0,68 & 6,1 & $95 \%$ \\
\hline Castor & 48 & 1307 & 9 & 24700 & $0,92-1,56$ & 4,6 & $89 \%$ \\
\hline Microalgae* & 50 & 97800 & 0,1 & $591-3276$ & $3,96-10,56$ & 8,9 & $60 \%$ \\
\hline
\end{tabular}

* Medium oil content, cultured in photobioreactors. 
Also, a global problem with high negative impacts in the environment is the release of industrial and do Table mestic wastewater to water bodies. Wastewater is commonly rich in organic compounds, phosphates and nitrates, eutrophication that can be solved by microalgae cultivation in this source, as regards the growth of microalgae in wastewater (Shi, Deng \& Zhao, 2004). The benefit is two-fold: improving the quality of effluents by removing components of soluble organic and inorganic pollutants, and growing biomass that can be used to obtain various products. In addition, wastewater remediation by microalgae is an environmentally process and does not produce secondary pollution as long as the biomass produced is reprocessed and allows efficient nutrient recycling, (Martínez, Sánchez, Jiménez, El-Yousfi \& Muñoz, 2000). Growing microalgae in wastewater is an alternative to the tertiary treatment of wastewater, because they recycle the nutrients responsible for eutrophication to make them usable biomass (Craggs, McAuley \& Smith, 1997), all issues mentioned above improves the sustainability of a microalgae-based biorefinery.

\section{ENERGY BALANCE OF A BIOREFINERY SETTING}

A technically viable biorefinery setting should be related to its positive energy balance, stages as the biomass drying, harvesting by centrifugation or microwaveassisted lipid extraction involves high energy requirements (Lee et al., 2010). Is important to take into account that harvesting of microalgae is a critical point in its use as a feedstock for a topology of biorefinery focused in energy-related products. According to results presented by Danquah, Ang, Uduman, Moheimani and Forde (2009), is clear that biomass concentration determines the energy demand of harvesting and drying stages; for this reason, optimization of energy demand is especially important when the cell concentration in the cultivation system is low, e.g. open ponds; comparison of different harvesting technologies made by the authors mentioned above, shows that when the biomass concentration becomes higher than $9 \mathrm{~g} / \mathrm{L}$, the differences between energy demand of different separation technologies as centrifugation or tangential flow filtration decreases. As far as energy studies, these requirements have to be evaluated and quantified in order to select a set of methods that will enable them to produce more units of energy than those consumed. A methodology that can be applied to do this is the exergy analysis, which calculates the irreversibilities of a process and compares processes in terms of energy used, as a first approach of that, Peralta, Sánchez and Kafarov (2010) evaluated transesterification of microlagal oil stage through exergetic balances and application of exergy efficiencies to locate irreversibilities in this stage, finding an exergetic efficiency of $79 \%$ and identifying exergy losses in residues of the process.

\section{CONCLUSIONS}

- The biorefinery concept has been identified as the most promising way for the creation of an biomassbased industry. It has advantages over linear processes of biomass transformation using waste materials, and the increase in bioproducts obtainable per unit area and the expectation to revitalize rural areas, which is why it should be taken into consideration when it comes to looking for a use for raw materials. Incorporating this concept in biofuel production chains can make the use of a raw material viable through the valuation of the by-products generated. Microalgae have high potential for use as a raw material in biorefinery processes because they contain different metabolites of interest and currently are used to obtain different products in linear production chains. In addition, since their use as a raw material to produce biofuels has raised global interest over the past few years, various methods have been developed to obtain oil from microalgae which can be used in a microalgae-based biorefinery setting.

- Data from literature shows some of the advantages of this technology to obtain biofuels and high value products: increased photosynthetic efficiency than with other plant organisms, possibility of growing in saline, hypersaline and fresh water, and industrial and domestic wastewater, potential to reduce carbon emissions based on where it is grown, fast growth rates, possibility of daily harvest for some strains. Advantages focused in algal biofuels are its no sulfur contain derived from the raw material, high 
biodegradability, and high levels of polyunsaturates in algae biodiesel suitable for its use in cold weather climates. Main disadvantages are the high production and transformation costs, high freshwater requirements for cultivation, and high acid value of microalgal oil in comparison with other biofuels feedstocks. Technologies for downstream processing are emerging and, until now, they have performed poorly compared to the mainstream alternative.

- The development of a biorefinery setup based on this raw material has to bear in mind several aspects such as the biomass productivity of the microalgae strain to be used and the composition thereof, since the percentages of lipids, carbohydrates, proteins, cellulosic material and other special substances are the first criterion to determine the advisability of extracting a certain product. It also has to take into account the market for the different products obtainable from microalgae to be used in order to determine the appropriateness of their development. Therefore, an important component in research related to microalgae biomass is the characterization of the strains to be used. Chemistry and biology play a key role in this part. In terms of configuration and technical details, chemical engineering can deal with these aspects using tools such as design, synthesis and integration of processes, exegetical analysis and techno-economic appraisals, while petroleum engineering is absolutely necessary due to the vast experience required in the fractioning and refining of components, and in obtaining fuel.

\section{ACKNOWLEDGMENTS}

The authors would like to thank the Ministry of Agriculture and Rural Development for its support through project 2008D32006-6710 "Bioprospecting of Colombian Microalgae for Biodiesel Production", the Ecopetrol S.A. - Instituto Colombiano del Petróleo $(I C P)$, the Latin American Program of Science and Technology for Development (CYTED), International Project 306RTO279 "New technologies for biofuel production", UNESCO Code 330303, 332205, 530603, 330399.

\section{REFERENCES}

Álvarez, Y., González, A. \& Kafarov, V. (2011). Development of a methodology for microalgae oil extraction with ethanol/hexane using thermal and chemical cell disruption. The First International Conference on Algal Biomass, Biofuels and Byproducts, St Louis, United States. P3-24.

Amaro, H., Guedes, C. \& Malcata, X. (2011). Advances and perspectives in using microalgae to produce biodiesel. Applied Energy, 88 (10), 3402-3410.

Amin, M. \& Wijffels, R. (2004). Milking of microalgae. Trends. Biotechnol., 22 (4), 189-194.

Amin, S. (2009). Review on biofuel oil and gas production processes from microalgae. Energy Convers. Manage., 50 (7), 1834-1840.

Anderson, J. \& Sorek, B. (2008). Microalgae: The fuel of tomorrow. Ninth Annual Freshman Conference. Pittsburgh, Pennsylvania, United States. 9112:C7

Berrios, M., Martín, M. A., Chica, A. F. \& Martín, A. (2010). Study of esterification and transesterification in biodiesel production from used frying oils in a closed system. Chem. Eng. J., 160 (2), 473-479.

Biofuels Research Advisory Council. (2006). Biofuels in the European union: A vision for 2030 and beyond. Final draft report. [Report in PDF format].[Accessed: June 13, 2011]. Available at: < http://ec.europa.eu/research/ energy/pdf/draft_vision_report_en.pdf>

Bligh, E. G. \& Dyer, W. J. (1959). A rapid method of total lipid extraction and purification. Can. J. Biochem. Physiol., 37 (8), 911-917.

Bush, R. A. \& Hall, K. M. (2006). Process for the production of ethanol from algae. U.S. Patent 7,135,308.

Carriquiry, M., Xiaodong, D. \& Govinda, R. (2011). Second generation biofuels: Economics and policies. Energy Policy, 39 (7), 4222-4234.

Chen, C. Y., Yeh, K. L., Aisyah, R., Lee, D. J. \& Chang, J. S. (2011). Cultivation, photobioreactor design and harvesting of microalgae for biodiesel production: A critical review. Bioresource Technol., 102 (1), 71-81. 
Cherubini, F. (2010).The biorefinery concept: using biomass instead of oil for producing energy and chemicals. Energy Convers. Manage., 51 (7), 1412-1421.

Chester, T. L. \& Pinkston, J. D. (2004). Supercritical fluid and unified chromatography, Anal. Chem., 76 (16), 4606-4613.

Cheung, P. C. K. (1999). Temperature and pressure effects on supercritical carbon dioxide extraction of n_ 3 fatty acids from red seaweed. Food Chemistry, 65 (3), 399-403.

Chisti, Y. (2007). Biodiesel from microalgae. Biot. Adv., 25 (3), 294-306.

Chisti, Y. (2008). Biodiesel from microalgae beats bioethanol. Trends Biotechnol., 26 (3), 126-131.

Clarens, A., Resurreccion, E. P., White, M. A. \& Colosi, L. A. (2010). Environmental life cycle comparison of algae to other bioenergy feedstocks. Environ. Sci. Technol., 44 (5), 1813-1819.

Córdoba, L. S., López, L. M., González, A. D. \& Kafarov, V. (2010). Microalgae lipid extraction by combining cell disruption and Soxhlet extraction method for biodiesel production. (inspanish). XXIX Latin American Chemistry Congress, Cartagena, Colombia. MYE 113.

Craggs, R., McAuley, P. \& Smith, V. (1997). Wastewater nutrient removal by marine microalgae grown on a corrugated raceway. Water Research, 31 (7), 1701-1707.

Cravotto, G., Boffa, L., Mantegna, S., Perego, P., Avogadro, M. \& Cintas, P. (2008). Improved extraction of vegetable oils under high-intensity ultrasound and/or microwaves. Ultrason. Sonochem, 15 (5), 898-902.

Danquah, M. K., Ang, L., Uduman, N., Moheimani, N. \& Forde, G. M. (2009). Dewatering of microalgal culture for biodiesel production: exploring polymer flocculation and tangential flow filtration. J. Chem. Technol. Biotechnol, 84 (7), 1078-1083.

Demirbas, A. (2007). Progress and recent trends in biodiesel fuels. Energy Convers. Manage., 50 (1), 14-34.

Demirbas, A. (2008). Biofuels sources, biofuel policy, biofuel economy and global biofuel projections. Energy Convers. Manage, 49 (8), 2106-2116.

Dias, M. O. S., Modesto, M., Ensinas, A. V., Nebra S. A., Maciel-Filho, R. \& Rossell, C. E. V. (2010). Improving bioethanol production from sugarcane: Evaluation of distillation, thermal integration and cogeneration systems Energy, 36 (6), 3691-3703.

Ehimen, E. A., Sun, Z. F. \& Carrington, C. G. (2010).Variables affecting the in situ transesterification of microalgae lipids. Fuel, 89 (3), 677-684.

Folch, J., Lees, M. \& Stanley, G. H. S. (1957). A simple method for the isolation and purification of total lipids from animal tissues. J. Biol. Chem., 226 (1), 497-509.

Fore, S. R., Lazarus, W., Porter, P. \& Jordan, N. (2011). Economics of small-scale on-farm use of canola and soybean for biodiesel and straight vegetable oil biofuels. Biomass Bioenergy, 35 (1), 193-202.

Franceschin, G., Zamboni, A., Bezzo, F. \& Bertucco, A. (2008). Ethanol from corn: a technical and economical assessment based on different scenarios. Chem. Eng. Res. Des., 86 (5), 488-498.

Garibay-Hernández, A., Vázquez-Duhalt, R., Sánchez-Saavedra, M., Serrano-Carreón, L. \& Martínez-Jiménez, A. (2009). Biodiesel a partir de microalgas. BioTecnología, 13 (3), 38-56.

Gerbens-Leenes, W., Hoekstra, A. Y. \& Meer, van der,T. H., (2009). The water footprint of bioenergy. PNAS, 106 (25), 10219-10223.

Goh, C. S. \& Lee, K. T. (2011). Second-generation biofuel (SGB) in Southeast Asia via lignocellulosic biorefinery: Penny-foolish but pound-wise. Renew. Sust. Energ. Rev., 15 (6), 2714-2718.

Goldemberg, J., Coelho, S. T. \& Guardabassi, P. (2008). The sustainability of ethanol production from sugarcane. Energy Policy, 36 (6), 2086-2097.

Gong Bih Enterprise Limited Company. (GONG). (2002). Components of Chlorella pyrenoidosa, Gong Bih Enterprise Limited Company. [Characterization certificate scan]. [Accessed: May 5, 2011]. Available at: <http:// www.gongbih.com/webc/html/chlorella/ch402.htm.>

González, A. D. \& Kafarov, V. (2010). Design of a multifunctional reactor for third generation biofuels production. Chem. Eng. Transact., 21 (1), 1297-1302.

Grierson, S., Strezov, V., Ellem, G., McGregor, R. \& Herbertson, J. (2009). Thermal characterisation of microalgae 
under slow pyrolysis conditions. J. Anal. Appl. Pyrolysis, 85 (1-2), 118-123.

Harun, R. \& Danquah M. (2011). Enzymatic hydrolysis of microalgal biomass for bioethanol production. Chem. Eng. J., 168 (3), 1079-1084.

Harun, R., Singh, M., Forde, G. M. \& Danquah, M. K. (2010). Bioprocess engineering of microalgae to produce a variety of consumer products. Renew. Sust. Energ. Rev., 14 (3), 1037-1047.

Henriques, M., Silva, A. \& Rocha, J. (2007). Extraction and quantification of pigments from a marine: A simple and reproducible method. Communicating Current Research and Educational Topics and Trends in Applied Microbiology, 1 (1), 586-593.

Herrero, M., Ibáñez, E., Señoráns, F. J. \& Cifuentes, A. (2003). Accelerated solvent extracts from Spirulinaplatensis Microalgae: determination of their antioxidant activity and analysis by Micellar Electrokinetic Chromatography. $J$. Chromatogr., 1047 (2), 195-203.

Herrero M., Cifuentes A. \& Ibáñez E. (2006). Sub- and supercritical fluid extraction of functional ingredients from different natural sources: Plants, food-by-products, algae and microalgae: A review. Food Chemistry, 98 (1), 136-148.

Hincapié, G., Mondragón, F. \& López, D. (2011). Conventional and in situ transesterification of castor seed oil for biodiesel production. J. Fuel, 90 (4), 1618-1623.

Hoekman, S. K. (2009). Biofuels in the U.S. challenges and opportunities. Renew. Energy, 34 (1), 14-22.

Holm-Nielsen, J. B., Al-Seadi, T. \& Oleskowicz-Popiel, P. (2009). The future of anaerobic digestion and biogas utilization. Bioresource. Technol., 100 (22), 5478-5484.

IEA Bioenergy, (2007). Task 42 on biorefineries: coproduction of fuels, chemicals, power and materials from biomass. Minutes of the third Task meeting. International Energy Agency. [Report in PDF format]. [Accessed: May 5, 2011]. Available at: < http:// www.biorefinery.nl/fileadmin/biorefinery/docs/Final_Description_IEA_Task_on_Biorefineries.pdf>.

Kamm, B., Kamm, M., Gruber, P. R. \& Kromus, S. (2006). Biorefinery systems - an overview. In: Kamm B, Gruber
PR, \& Kamm M, editors. Biorefineries - industrial processes and products: Status quo and future directions (Vol. 1. Weinheim, Germany. Wiley-VCHVerlag GmbH.

King, J. (2000). Advances in critical fluid technology for food processing. Food. Sci. Tech. Today, 14 (4), 186-191.

Kumar, P., Barrett, D. M., Delwiche, M .J. \& Stroeve, P. (2009). Methods for pretreatment of lignocellulosic biomass for efficient hydrolysis and biofuel production. Ind. Eng. Chem. Res., 48 (8), 3713-3729.

Lee, S. J., Yoon, B. D. \& Oh, H. M. (1998). Rapid method for the determination of lipid from the green alga Botryococcus braunii, Biotechnol. Tech., 12 (7), 553-556.

Lee, J. Y., Yoo, C., Jun, S. Y., Ahn, C. Y. \& Oh, H. M.(2010). Comparison of several methods foreffective lipid extraction from microalgae. Bioresource. Technol., 101 (1), 575-577.

Li, Y., Ruan, R., Chen, P. L., Liu, Z., Pan, X. \& Lin, X. (2004). Enzymatic hydrolysis of corn stover pretreated by combined dilute alkaline treatment and homogenization. Trans. ASAE 47 (3), 821-825.

Li, Y. Q., Horsman, M., Wang, B., Wu, N. \& Lan, C. Q. (2008). Effects of nitrogen sources on cell growth and lipid accumulation of green alga Neochloris oleoabundans. Appl. Microbiol. Biotechnol. 81 (4), 629-636.

Manirakiza, P., Covaci, A. \& Schepens, P. (2001).Comparative study on total lipid determination using Soxhlet, RoeseGottlieb, Bligh \& Dyer, and modified Bligh \& Dyer extraction methods. J. Food. Acid Gas Anal., 14 (1), 93-100.

Martínez, M., Sánchez, S., Jiménez, J., El-Yousfi, F. \& Muñoz, L. (2000). Nitrogen and phosphorus removal from urban wastewater by the microalga Scenedesmus obliquus.Bioresource. Technol., 73 (3), 263-272.

Mata, T. M., Martins, A. A. \& Caetano, N. S. (2010). Microalgae for biodiesel production and other applications: a review. Renew. Sustain. Energy. Rev., 14 (1), 217-232.

Mekonnen, M. M. \& Hoekstra, A. Y. (2011). The green, blue and grey water footprint of crops and derived crop products. Hydrol. Earth Syst. Sci., 15 (1), 1577-1600.

Mendes-Pinto, M. M., Raposo, M. F. J., Bowen, J., Young, A. J. \& Morais, R. (2001). Evaluation of different cell disruption processes on encysted cells of Haematococcus pluvialis: 
effects onastaxanthin recovery and implications for bioavailability. J. App. Phycol., 13 (1), 19-24.

Mendes, R. L., Fernandes, H. L., Coelho, J. P., Reis, E. C., Cabral, J. M. S., Palavra, A. F. \& Novais, J. M. (1995). Supercritical $\mathrm{CO}_{2}$ extraction of carotenoids and other lipids from Chlorella vulgaris. Food Chemistry, 53 (1), 99-103.

Mendes, R. L., Nobre, B. P., Cardoso, M. T., Pereira, A. P. \& Palavra, A. F. (2003). Supercritical carbon dioxide extraction of compounds with pharmaceutical importance from microalgae. Inorg. Chim. Acta, 356 (1), 328-334.

Meng, X., Yang, J., Xu, X., Zhang, L., Nie, Q. \& Xian, M. (2009). Biodiesel production from oleaginous microorganisms. Renew. Energy. 34 (1), 1-5.

Minowa, T., Yokoyama, S., Kishimoto, M. \& Okakurat, T. (1995). Oil production from algal cells of Dunaliella tertiolecta by direct thermochemical liquefaction. Fuel, 74 (12), 1735-1738.

Moen, E. (2008). Biological degradation of brown seaweeds. The potential of marine biomass for anaerobic biogas production. Scottish Association for Marine Science Oban. Argyll, Scotland.

Molina-Grima, E., Acién-Fernández, F. G., García-Camacho, F. \& Chisti, Y. (1999). Photobioreactors: light regime, mass transfer, and scaleup. J. Biotechnol., 70 (1), 231-247.

Molina-Grima, E., Robles-Medina, A., Giménez-Giménez, A., Sánchez-Pérez, J., García-Camacho, F. \& García-Sánchez, J. (1994). Comparison between extraction of lipids and fatty acids from microalgal biomass, J. Am. Oil Chem. Soc., 71 (9), 955-959.

Molina, E., Fernández, J., Acién, F. \& Chisti, Y. (2001). Tubular photobioreactor design for algal cultures. J. Biotechnol., 92 (2), 113-131.

Mortimer, N. D., Elsayed, M. A. \& Horne, R. E. (2004). Energy and greenhouse gas emissions for bioethanol production from wheat grain and sugar beet. Final Report. UK: British Sugar Plc. [Text document]. [Accesed: May 5, 2011]. Available at: <http://www.northenergy. co.uk/c/pdf/ Resources_Research_Unit-Work_for_British_Sugar-2_1.pdf $>$.
Mueller, S., Anderson, J. \& Wallington, T. (2011). Impact of biofuel production and other supply and demand factors on food price increases in 2008. Biomass Bioenergy, 35 (5), 1623-1632.

Naik, S. N., Goud, V. V., Rout, P. K. \& Dalai, A. K. (2010). Production of first and second generation biofuels: a comprehensive review. Renew. Sust. Energ. Rev., 14 (2), 578-597.

Nigam, P. \& Singh, A. (2011). Production of liquid biofuels from renewable resources. Prog. Energy Combust. Sci., 37 (1), 52-68.

Ojeda, K., Ávila, O., Suárez, J. \& Kafarov, V. (2010). Evaluation of technological alternatives for process integration of sugarcane bagasse for sustainable biofuels production - part 1. Chem. Eng. Res. Des., 89 (3), 270-279.

Olivares-Carrillo, P. \& Quesada-Medina, J. (2011), Synthesis of biodiesel from soybean oil using supercritical methanol in a one-step catalyst-free process in batch reactor. $J$. Supercrit. Fluid., 58 (3), 378-384.

Otsuka, K. \& Yoshino, A. (2004). A fundamental study on anaerobic digestion of sea lettuce. Ocean'04 - MTS/IEEE Techno-Ocean'04: Bridges across the Oceans - Conference Proceedings. Ocean'04 - MTS/IEEE Techno-Ocean'04. [Text document]. [Accessed: May 5, 2011]. Available at: $<\mathrm{http}$ ://ieeexplore.ieee.org/xpls/abs_all. jsp?arnumber $=1406392 \& \operatorname{tag}=1>$

Peralta, Y., Sánchez, E. \& Kafarov, V. (2010). Exergy analysis for third generation biofuel production from microalgae biomass. Chem. Eng.Transact., 21 (1), 1363-1368.

Pernet, F. \& Tremblay, R. (2003). Effect of ultrasonication and grinding on the determination of lipid class content of microalgae harvested on filters. Lipids, 38 (11), 1191-1195.

Richmond, A. (2004). Handbook of microalgal culture: biotechnology and applied phycology. Ames, Iowa, Unites States: Blackwell Science.

Robles-Medina, A., Molina-Grima, E., Giménez-Giménez, A. \& Ibáñez-González, M. J. (1998), Downstream processing of algal polyunsaturated fatty acids. Biotech. Adv., 16 (3), 517-580.

Santana, G. C. S., Martins, P. F., de Lima da Silva, N., Batistella, C. B., Maciel-Filho, R. \& Wolf-Maciel, M. R. (2010). 
Simulation and cost estimate for biodiesel production using castor oil. Chem. Eng. Res. Des., 88 (5-6), 626-632.

Schenk, P. M., Thomas-Hall, S. R., Stephens, E. Marx, U. C., Mussgnug, J. H., Posten, C., Kruse, O. \& Hankamer, B. (2008). Second Generation Biofuels: High-Efficiency Microalgae for Biodiesel Production. Bioenerg. Res., 1 (1), 20-43.

Searchinger, T., Heimlich, R., Houghton, R. A., Dong, F., Elobeid, A., Fabiosa, J., Tokgoz, S., Hays, D. \& Yu, T. H. (2008). Use of US croplands for biofuels increases greenhouse gases through emissions from land-use change. Science, 319 (5867), 1238-1240.

Shi, D., Deng, Y. \& Zhao, X. (2004).Cyanobacterial genetic engineering technology for recombinant pharmaceutical products. National Medicine Bioengineering Seminar of Chinese Society of Biotechnology: 54.

Singh, S. P. \& Singh, D. (2010). Biodiesel production through the use of different sources and characterization of oils and their esters as the substitute of diesel: a review. Renew. Sustain. Energ. Rev., 14 (1), 200-216.

Spath, P. L. \& Dayton, D. C. (2003). Preliminary screening - technical and economic assessment of synthesis gas to fuels and chemicals with emphasis on the potential for biomass-derived syngas. NREL task no. BBB3.4210, Colorado. U.S.A.

Taylor, G. (2008). Biofuels and biorefinery concept. Energy Policy, 36 (12), 4406-4409.

Ueda, R., Hirayama, S., Sugata, K. \& Nakayama, H. (1996). Process for the production of ethanol from microalgae. U.S. Patent 5: 578-472.

Vázquez-Duhalt, R. \& Arredondo-Vega, B. (1991). Haloadaptation of the green alga Botryococcus braunii (race a). Phytochemistry, 30 (9), 2919-2925.

Ward, O. P. \& Singh, A. (2005). Omega-3/6 fatty acids: Alternative sources of production. Process Biochem., 40 (12), 3627-3652.

Wyman, C. E. (2001). Economics of a biorefinery for coproduction of succinic acid, ethanol, and electricity. Abstracts of Papers of the American Chemical Society. 221 P. U119U119. Part 1 Meeting Abstract: 72-BIOT.
Xiong, W., Fu, Y., Zeng, F. \& Guo, Q. (2011). An in situ reduction approach for bio-oil hydroprocessing. Fuel Process. Tech., 92 (8), 1599-1605.

Xu, H., Miao, X. \& Wu, Q. (2006). High quality biodiesel production from a microalga Chlorella protothecoides by heterotrophic growth in fermenters. J. Biotechnol., 126 (4), 499-507.

Yang, J., Xu, M., Zhang, X., Hu, Q., Sommerfeld, M. \& Chen, Y. (2011). Life-cycle analysis on biodiesel production from microalgae: Water footprint and nutrients balance. Bioresource Technol., 102 (1), 159-165.

Yusuf, N. N. A. N., Kamarudin, S. K. \& Yaakub, Z. (2011). Overview on the current trends in biodiesel production. Energy Convers. Manage., 52 (7), 2741-2751. 


$$
\text { - }
$$

